\title{
Juris Svaža
}

\section{OROPHARYNGEAL PATHOLOGY AND RESULTS OF SURGICAL TREATMENT OF PATIENTS WITH SLEEP DISTURBED BREATHING}

For obtaining the scientific degree

a Doctor of Medicine Speciality - Anaesthesiology-Reanimatology 


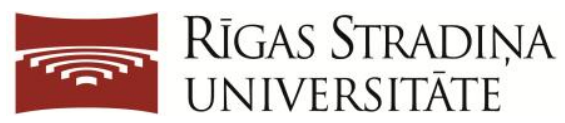

Juris Svaža

\section{OROPHARYNGEAL \\ PATHOLOGY AND RESULTS \\ OF SURGICAL TREATMENT OF PATIENTS WITH SLEEP DISTURBED BREATHING}

For obtaining the scientific degree a Doctor of Medicine

Speciality - Anaesthesiology-Reanimatology

Riga, 2013 
The doctoral thesis was elaborated:

at the Institute of Stomatology of Rīga Stradinšs University

Scientific supervisors:

Dr. habil. med., Professor Andrejs Skaǵers,

Rīga Stradiņš University (Latvia)

Dr. habil. med., Professor Indulis Vanags,

Rīga Stradinsš University (Latvia)

Official reviewers:

Dr. habil. med., Professor Ingrīda Čēma,

Rīga Stradinš̌ University (Latvia)

Dr. habil. med., Professor Juris Aivars,

University of Latvia (Latvia)

Dr. med., Assistant Professor Tālis Kauliṇš,

University of Latvia (Latvia)

The defence of doctoral thesis will be held on 16.12. 2013. at 15.30 in the open meeting of the Promotion Council, Rīga Stradiņš University, Lecture theatre Hippocrates, 16 Dzirciema street, Riga.

Full text available in the Library of RSU or RSU website: www.rsu.lv

The thesis was co-funded by the ESF project "Support to implementation of doctoral study programmes and obtaining the scientific degree at RSU", agreement No. 2009/0147/1DP/1.1.2.1.2/09/IPIA/VIAA/009.

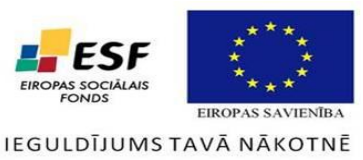

Secretary of the Promotion Council:

Dr. habil. med., Professor Ingrīda Čēma 


\section{Contents}

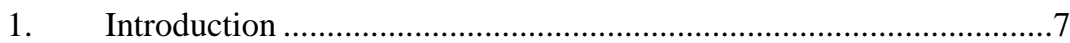

1.1. Scientific topicality of the paper....................................................

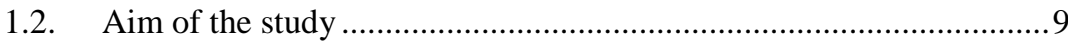

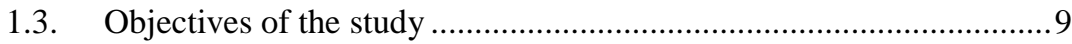

1.4. Scientific novelty of the study ……................................................ 10

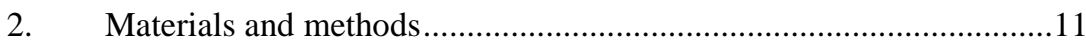

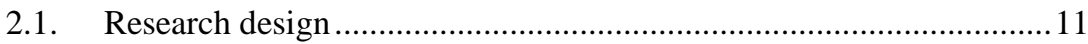

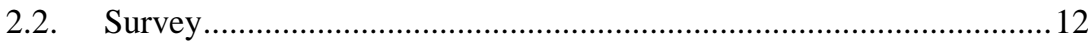

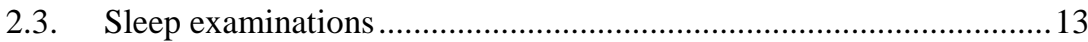

2.4. Radiological examinations of upper airway .................................... 14

2.5. Endoscopy of upper airway during drug-induced sleep ..................... 14

2.6. Pathomorphological examination of resected tissue samples .............15

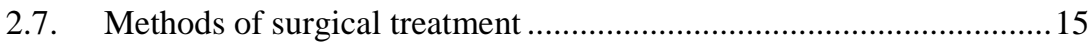

2.8. Use of Bispectral index for objective assessment of sleepiness in OSA patients ............................................................... 18

2.9. Analysis of the results and statistical processing .............................. 18

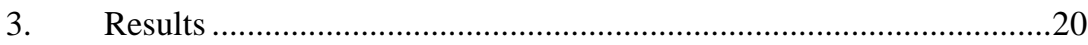

3.1. Anthropometric and clinical data of patients entered in the study......20

3.2. Assessment of efficiency of surgical treatment .................................21

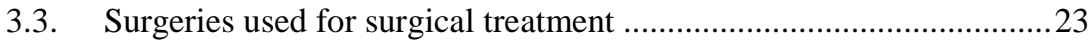

3.4. PSG results and impact of certain physical parameters on

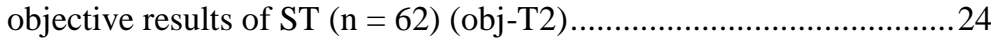

3.5. PSG results and impact of certain physical parameters on subjective results of ST (subj.-T1 and subj.T2).............................26

3.6. Comparison of airway sagittal dimensions ......................................28

3.7. Histological findings of upper airway soft tissue samples

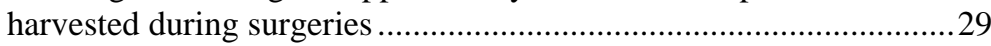

3.8. Use of Bispectral index for determination of sleepiness .....................30 


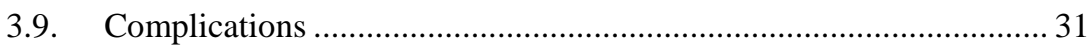

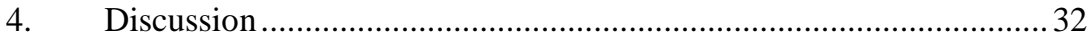

4.1. Description and comparison of surgical treatment results ................ 32

4.2. The analysis of our study results and comparison with results

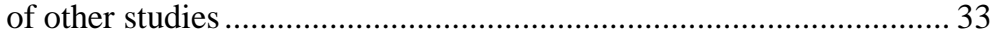

4.3. The analysis of factors affecting ST results ....................................... 34

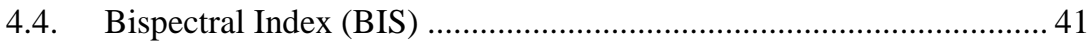

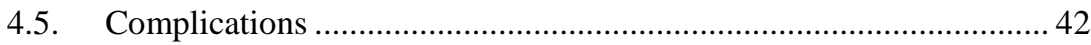

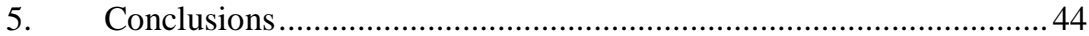

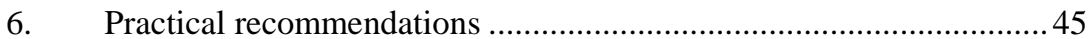

7. AUTHOR'S PUBLICATIONS ON THE RESEARCH SUBJECT ... 47

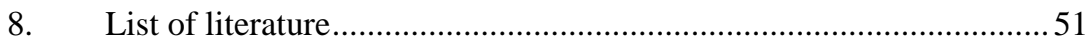




\section{ABBREVIATIONS}

AHI

ANP

$\mathrm{CO}_{2}$

CSE

CPAP

EEG

ECG

EMG

EOG

ESS

GAHM

GA

GERS

BMI

BIS

LC

MAR

MLS

NREM

OSA

OSAHS

OSAS

PG

PSG

PAP

RF
Apnea - Hypopnoea Index

Atrial Natriuretic Peptide

Carbon Dioxide

Cheyne-Stokes Respiration

Continuous Positive Airway Pressure

Electroencephalogram

Electrocardiogram

Electromyogram

Electroretinogram

Epworth Sleepiness Scale

Genioglossus Advancement /Hyoid Miotomy

Genioglossus Advancement

Gastro-Oesophageal Reflux Disease

Body Mass Index

Bispectral index

Lateral Cephalogram

Mandibular Repositioning Appliances

Multi Leve Surgery

Nonrapid Eye Movement Sleep

Obstructive Sleep Apnea

Obstructive Sleep Apnea/Hypopnoea Syndrome

Obstructive Sleep Apnea Syndrome

Poligraphy

Polysomnography

Positive Airway Pressure Therapy

Radio Frequency Surgery 
RFTBR Radio Frequency Tongue Base Reduction

RP Rhinoplasty

SNS Sympathetic Nervous System

SP Septoplasty

$\mathrm{SpO}_{2} \quad$ Oxygen Saturation In Blood

ST Surgical treatment

UA Upper Airway Resistance Syndrome

UARS Upper Airway

UPP Uvulopalatoplasty

UPPP Uvulopalatopharyngoplasty

TE Tonsilectomy

TT Turbinotomy 


\section{INTRODUCTION}

\subsection{Scientific topicality of the paper}

The term Obstructive Sleep Apnea (OSA) was first introduced in 1972, and it is used in reference to a certain pathological condition in which breathing stops during sleep. When the number of respiratory disorders is large, and this condition continues throughout several years along with typical clinical signs and symptoms, the term Obstructive Sleep Apnea Syndrome (OSAS) is used. In our work, the term which is used the most, is OSA. It refers to disturbed breathing during sleep. Where it is necessary to stress the severity of OSA, respectively, its systemic complications, the term OSAS is applied.

According to literature, OSA generally affects 3-7\% of adult men and 2$5 \%$ of adult women [1]. Results of the study of 2003 show that among primary care patients with a history of cardiovascular disease or metabolic disorders an increased risk of OSA is found in $38 \%$ of men and $28 \%$ of women [2]. Other populations of increased OSA risk include patients with diabetes mellitus - 36\% prevalence, with resistant hypertension - $63 \%$ prevalence, first-time stroke 44 to $72 \%$ prevalence, hypothyroidism - $45 \%$ prevalence, alcoholism - $17 \%$ prevalence, acromegaly - $<80 \%$ prevalence. According to epidemiological data ("Wisconsin Sleep Cohort"), among obese patients with BMI> 40, moderate to severe OSA is observed in $42-55 \%$ of men and $16-24 \%$ of women.

Structural narrowing of upper airway plays an important role in pathogenesis of OSA, however, the most common cause is obesity-induced fatty infiltration of parapharyngeal tissue [3], and significant obesity is a predominant trigger of OSA [4]. Apnea is defined as cessation of airflow at the nose and mouth lasting at least 10 seconds. A condition of reduced and insufficient airflow but not a complete cessation is called hypopnoea. The number of these episodes is used to classify the severity OSA and the number of both of these events per hour of sleep is called apnea-hypopnoea index (AHI 
- number of cases/1 hour of sleep). The higher is AHI, the more severe the form of OSA. AHI $<5$ episodes/h is a normal range, AHI 5 -15 is defined as mild OSA, AHI 15 - 30 as moderate form of OSA, AHI > 30 episodes $/ \mathrm{h}$ indicates a severe form of OSA.

OSAS is associated with significant comorbidities. Professional associations of cardiologists, neurologists, endocrinologists in the EU, the USA and other countries have included OSAS in their guidelines as one of the causes of hypertension and increased risk of cardiovascular disease [11, 5], diabetes type II [6], metabolic syndrome and cognitive disorders [7]. The Council of the European Union is working on the Directive 91/439/EEC, which provides inclusion of severe forms of OSAS into the list of medical conditions disqualifying a person from obtaining a driver's license [8]. OSAS is also associated with increased perioperative risk.

Over recent decades, many articles are published on surgical treatment of OSA, however, conclusions about its efficiency are controversial. Similarly, several types of surgical treatment are offered. The idea to start diagnostics and treatment of OSA at the Institute of Stomatology of RSU, as well as to conduct a research on the above subject arouse in 2000. There were several grounds behind this decision:

1. Previously OSAS was a little-known diagnosis in Latvia. The syndrome was not diagnosed and treated as a separate medical condition. There was also no research conducted on the above subject.

2. The Institute of Stomatology of RSU had a sufficient experience and resources to launch diagnosis and treatment of OSA. The Oral and Maxillofacial Surgery Clinic and the Orthodontic Clinic had already conducted scientific studies on upper airway morphology and craniofacial pathology and its treatment.

3. The Sleep Laboratory was established and diagnostic of OSA was launched. Also treatment of severe form of OSA with positive airway pressure 
method was started. Consequently, the Institute of Stomatology of RSU had all the conditions necessary for OSA diagnostics and for treatment and research of many profiles.

Scientific assumption of working hypothesis

Upper airway structural and pathomorphological changes as well as physical signs and symptoms in the patients suffering from the sleep disturbed breathing, could be used as predictors of surgical treatment success.

\section{Ethical concerns}

The study was approved by the Comity of Ethics, Riga Stradiņš University

\subsection{Aim of the study}

To determine structural and pathomorphological changes of upper airway in patients with obstructive sleep apnea, who later have had upper airway soft tissue corrective surgeries, in order to elaborate recommendations for individual treatment plans.

\subsection{Objectives of the study}

1. To evaluate cephalometric indices of upper airway in patients with various degrees of respiratory disturbances during sleep.

2. To evaluate pathomorphological changes of upper airway soft tissues removed during the course of surgery from patients with various degrees of respiratory disturbances during sleep.

3. To evaluate clinical efficacy of surgical treatment based on patients' subjective and objective evaluations.

4. To determine correlation between cephalometric indices of upper airway, morphological changes of the material obtained during surgeries, 
patients' anthropometric and clinical data, surgical techniques applied and patients' individual characteristics.

5. To assess sleepiness of OSA patients using BIS.

6. To summarize the results and to elaborate recommendations for drawups of individual surgical treatment plans.

\subsection{Scientific novelty of the study}

1. No diagnostic and treatment of obstructive sleep apnea as a separate medical condition has been carried out in Latvia, before

2. No studies on the use of Bispectral Index for objective assessment of sleepiness in OSA patients have been carried out up to date.

3. During the research, which lasted 10 years, we have developed recommendations for surgical treatment, which are based on specific anatomical and clinical parameters.

The study covers 164 pages including 5 annexes, 267 references 92 figures and 11 tables. 


\section{MATERIALS AND METHODS}

\subsection{Research design}

The study was conducted from 2003 through November 2012 at the Institute of Stomatology of RSU. Of all surgically treated patients, in the study we included 97 patients, from whom it was possible to obtain the necessary data. These patients had approached for assistance due to snoring and/or suspicion of OSA. They underwent sleep tests (PSG, PG) and a survey (including survey of relatives) and were found having disturbed breathing during sleep - snoring or various degrees of OSA. Patients were offered treatment options: positive pressure therapy (PST) in cases of severe and moderate forms of OSA, surgical methods or oral appliances in cases of milder OSA and for prevention of snoring. Patients who opted for surgical treatment (ST) were introduced with all treatment options, informed of existent possibilities and complications. Prior to the final decision regarding ST, the essence of surgical tactics, possible alternatives, complications were repeatedly explained to the patients, and they confirmed their agreement in writing. Patients were warned of the impact of obesity on respiratory system and of the fact that with an increase of body weight, respiratory disorders during sleep will return.

\section{Following anthropometric and clinical data were obtained before surgery:}

- Demographic data: age (years), sex

- Anthropometric data: BMI, neck circumference, Mallampati class [9], palatine tonsil size according to Friedman's classification [10].

- Sleep examination data (AHI, mean blood oxygen saturation - $\mathrm{SpO}_{2}$ )

- The survey data (subjective sleepiness rating according to the Epworth Sleepiness Scale (ESS), snoring intensity). 


\section{Patients' data were obtained in the following chronological order:}

- $\quad$ Prior to ST: T0, anthropometric, clinical, survey and sleep examination data $(n=97)$,

- 3-6 months after surgery: subj.-T1, subjective evaluation of surgical results acquired during repeated survey $(n=94)$,

- $\quad 3$ - 4 years after surgery: subj-T2 $(n=67)$, subjective evaluation of ST results acquired during repeated survey, BMI, ESS and repeated sleep examinations in a part of the patients and late objective indices - obj.-T2 $(n=62)$. Postsurgical period of 12 patients was less than 3 years.

\section{Assessment of ST results:}

The objective assessment was based on re-examinations of sleep from which the Apnea-Hypopnoea Index (AHI) we selected for evaluation of the efficiency of treatment. AHI describes the severity of OSA and the mean blood oxygen saturation (mean $\mathrm{SpO} 2$ ). In similar studies, most frequently treatment results were compared using the above values. Sleep was re-examined in 62 patients. ST results were assessed as successful following the criteria established by Sher [11] where post-surgical AHI-T2 $<10$ or AHI-T2 < 20, but it has decreased by more than 50\% from pre-op. Assessments, which did not meet these criteria, were defined as negative.

\subsection{Survey}

Evaluation of ST results in patients with snoring was performed using questionnaires (T0, T1, T2). Snoring (T0, T1, T2) and somnolence (T0-T2) were assessed. Standard questionnaires were used in the study. Patient's questionnaire consisted of the following sections: passport and anthropometric 
data, medical history, medication therapy, main complaints, Epworth Sleepiness Scale (ESS), answers to questions related to driving a vehicle. Patients' bed partners in their questionnaires provided information about patients' breathing difficulties at night, snoring intensity and patients' sleepiness according to the ESS.

\subsection{Sleep examinations}

To determine severity of breathing disorders and to compare results of ST in OSA patients, polysomnography (PSG) and poligraphy (PG) data of sleep tests were used. The most important and widely used indicator of OSA severity is AHI (T0, T2) and mean $\mathrm{SpO}_{2}$ (T0, T2). Sleep examinations were conducted at the Sleep laboratory, where participants of the study spent overnight.

Apnea and hypopnoea were recorded according to standards of the American Academy of Sleep Medicine (AASM): apnea was defined as cessation of respiration for 10 seconds and hypopnoea was defined as insufficient airflow at the mouth and nose for not less than 10 seconds with at least a $20 \%$ reduction in the airflow and with at least a $4 \%$ oxygen desaturation. Nasal cannulas were used to determine the airflow. Pulse oxymetry - a noninvasive spectrophotometric method to measure oxygen saturation in capillary blood $\left(\mathrm{SpO}_{2}\right)$ - was performed. Heart rate frequency was registered via pulse oxymetry and ECG. Thoracic and abdominal respiratory movements were recorded with piezoelectric belts and snoring loudness was recorded with microphones. In case of PSG, electroencephalogram (EEG), elektrooculogram (EOG), chin and leg electromyograms (EMG) were also registered. A computer program processed statistical data, which were verified by an assistant of the sleep laboratory, and physician performed the final inspection of the results, as well as formulated conclusions. Sleep tests were conducted to determine 
severity of respiratory disorders, while re-examinations were carried out for monitoring treatment results. Late objective results of surgical treatment were obtained by repeating PSG and PG in 62 patients. The compared indices were AHI-T0 - AHI-T2, the mean $\mathrm{SpO}_{2}$-T0 and the mean $\mathrm{SpO}_{2}$-T2.

\subsection{Radiological examinations of upper airway}

Assessments of clinical significance of LC findings were performed on the grounds of several studies, which describe changes in airway of OSA patients and compare them with findings in patients without any signs and symptoms of OSA. Two Kollias's developed control groups of different ages were selected as reference points for normal LC indices. Length and thickness of uvula, size of velopharyngeal space, width of glossopharyngeal space and the condition of maxillofacial skeleton of 58 patients of the study were compared with data of the selected control groups as well as between patients with various degrees of sleep disturbed breathing. For all the patients, LC was performed with a standardized technique with a patient positioned upright, forward head posture (mirror technique), at the end of exhalation. Cephalometric analysis was conducted by two competent orthodontists. The measurements were taken blind against other data of patients, such as AHI, BMI, or other symptoms of OSA.

\subsection{Endoscopy of upper airway during drug-induced sleep}

DISE (Drug Induced Sleep Endoskopy) allows assessment of upper airway function under conditions which are the most approximated to natural sleep. Tendency to airway obstruction was assessed: in nasal cavity, at soft palate level (Velopharynx), oral cavity level (Oropharynx), at tongue base level and at epiglotis level. Based on recommendations to apply this method before surgical treatment of OSA, Institute of Stomatology of RSU uses the above 
technique since 2009. Researches show that DISE enables better planning of ST tactics and helps to avoid unsubstantiated surgeries [12]. No late results of application of DISE in patients prior to ST have been summarised yet, thus, our study lacks objective data on the efficiency of this technique.

\subsection{Pathomorphological examination of resected tissue samples}

Samples of surgically harvested UE tissues were examined at the Institute of Pathology of P. Stradins Clinical Univesity Hospital. Tissue materials were obtained during surgeries, and they were mostly obtained from uvula, soft palates and tonsils. The resected pieces of soft tissue were fixed in $10 \%$ neutral formalin solution, paraffin blocks were prepared after histological processing, sections were coloured with hematoxylin/eosin and with van Gieson's method + elastic fiber colouring, and Masson trichrome methods. Preparations were examined with the light microscope and photographed (at $100 \times$ magnification). While histological examination of the obtained materials, pathological changes were compared with the severity of respiratory disorders. All samples were numbered by randomly selected codes to ensure blind study. Pathomorphological changes were collected and divided into 4 groups depending on their severity: 0 - no change, 1 - minor changes, 2 - moderate changes, 3 - very explicit changes; and they were compared with the severity of respiratory disturbance, age and BMI.

\subsection{Methods of surgical treatment}

Selection and technical execution of certain surgical treatment methods was in line with worldwide accepted guidelines and recommendations. Selection of ST was based on two-stage surgical treatment protocol proposed by Powell and Riley. The first stage of the above protocol involves correction 
of soft tissue at different levels of upper airway depending on obstruction site, while the second stage comprises of skeletal corrective surgeries [13].

Overall, 157 surgeries were performed on 97 patients: uvulopalatoplasty (UPP) - 52, uvulopalatopharyngoplasty (UPPP) - 31, laser-uvulopalatoplasty (LAUPP) -3 , m. genioglossus and tongue advancement (GA) - 1 chin plasty (GP) -1 , conventional tonsilectomy (TE) -25 , open rinoplasty (RP) -16 , nasal septum plasty (SP) - 4, laser-uvulopalatoplasty (LAUPP) - 4, nasal valves strengthening with spreader graft $(\mathrm{SG})-4$, radiofrequency tonsillotomy $($ RFTT $)-2$, radiofrequency uvulopalatoplasty (RFUPP) -8 , radiofrequency tongue base reduction (RFTBR) - 8, maxillomandibular osteotomy with mandibular advancement (MMA ) - 2. While systematizing ST techniques, they were grouped by anatomical areas where they were performed in order to improve air flow, regardless of technical solution of the surgical technique conventional, laser or radio frequency technique.

Nasal corrections. In cases where patients had difficulties breathing through the nose, such nasal surgeries as septoplasty, closed and open rhinoplasty, strengthening of nasal valve were also performed as a part of ST. Nasal breathing is essential in development of the phenomenon of snoring. Nasal septum deviation is common abnormality, causing air turbulence in the nose and often is the reason for so-called palatine snoring. In such cases, a surgery for improvement of nasal breathing can eliminate snoring. Improvement of nasal respiratory function is essential also in case of PAP.

Soft palate surgeries. The most frequently applied surgeries aimed at removal of narrowing and/or occlusion at soft palate level were - UPP and UPPP. UPP was applied mainly in cases where no explicit augmentation of palatine tonsils was present and snoring was without severe respiratory disturbances and no airway narrowing at other levels were observed.

In cases where radiological, endoscopic and other data showed occlusions at soft palate level and pharyngeal wall level were very explicit, a 
larger palatine/throat wall plastic - UPPP - was required. In cases of explicitly enlarged tonsils, UPPP was often coupled with TE. At the early years of the study UPP was used more frequently, while after the first summarization of the results the tactic of ST became more radical and UPPP was applied more often.

Enlargement of oropharynx. In order to eliminate airway obstruction at the hypopharyngeal level, radio-frequency technique was applied for tongue base tissue reduction, m. genioglossus advancement and maxillo-mandibular advancement - by moving mandible forvaed for not less than $10 \mathrm{~mm}$.

Osteotomy with maxillo-mandibular advancement (MMA). Previous ST experience in the world shows that maxillo-mandibular advancement for no less than $10 \mathrm{~mm}$ is the next most effective surgical technique after tracheostomy. MMA surgeries were applied in two cases where patients were young persons with a severe OSA and with an skeletal abnormality retrognathic mandible. American Academy of Sleep Medicine has recognized this surgical technique as the most effective in average of $90 \%$ of cases [14].

Radio-frequency (RF) method. This technique was applied to reduce turbinate tissue volume in nasal cavity (turbinotomy), palate and palatine tonsil, oral cavity (RFUPP) and at the base of tongue (RFTBR). It is known that the potentials of RF tissue reduction are limited, therefore the procedure, most commonly, was used in conjunction with other surgeries, and in some cases surgeries were repeated.

Most frequently surgeries were combined. Often patienst underwent several surgeries due to having several obstructions. This tactic is called multilevel surgery - MLS. 


\subsection{Use of Bispectral index for objective assessment of sleepiness in OSA patients}

Bispectral index (BIS) is a figure that reflects brain activity and it is derived from four-channel electroencephalogram (EEC) by processing it with a special algorithm. BIS volume is a figure from 0 to 100, and it measures degree of brain activity. In this scale BIS index close to 100 shows high brain activity - vigil, while 0 is isoelectric EEG. Two study groups were developed: group of 48 patients with confirmed diagnosis of OSA (AHI>10) and control group comprised of 42 medical students without clinical signs and symptoms of OSA. Examination was performed in sleep laboratory within 24-hour period from 12:00 till 14:00. All participants were placed in a darkened room with enhanced sound isolation, in order to exclude external irritations as much as possible. Patients were asked to stay awake, and mean BIS scores were recorded for 15 minutes. All participants of the study also completed the ESS which reflected their subjective evaluation of the sleepiness. To assess the correlation of BIS index with AHI and ESS, the obtained data were compared between groups.

\subsection{Analysis of the results and statistical processing}

Statistical analysis of data was aimed at evaluation using appropriate statistical methods and at comparison of patients' anthropometric, clinical, sleep test, radiological imaging and resected soft tissue histological data; through assessment of ST efficiency, to compare sleep test data and survey data before and after treatment; to search for correlation between patients' anthropometric, physical and clinical data and ST results; to find most substantial factors influencing ST results. Based on the type of the variable, we calculated an indicator of central tendency - the arithmetic mean value, median and mode of the indicator, as well as dispersion ratio - standard deviation, minimum and maximum value of the indicator. 
To determine whether data were consistent with normal distribution, we used Shapiro-Wilk and Kalmagorov-Smirnov tests. To compare two dependent or independent groups by the same indicator, we used Student's t-test, but to compare several independent groups by the same indicator, we used analysis of variance (ANOVA). In all cases, results were assessed as statistically significantly different when the null hypothesis probability equalled to 0.05 or less, i.e., significance level $\mathrm{p}=0.05$ was a criterion for rejection of the null hypothesis. Otherwise, the null hypothesis was accepted.

For analysis of correlation between two indicators, Pearson's correlation analysis was used. The following classification of correlation proximity was adopted in the study depending on the value of the correlation coefficient $r$ :

- $\quad$ correlation is weak when $r \leq 0.3$;

- correlation is medium when $0.3<\mathrm{r}<0.7$;

- correlation is close when $r \geq 0.7$.

Link between two parameters was also searched using a linear regression method. For analysis of a nominal or a rank in data, in order to compare apportionment of two or more indications, Pearson's Chi-square statistical analysis (when contingency table frequency <5) was used, while the Fisher's exact test was used when the contingency table frequency $>5$.

To determine specification limit of two comparative groups, ROC (Receiver Operating Characteristic) curves were used. In order to compare quality of the specification limit, area under a curve (AUC) was used. In order to generalize the obtained results, $95 \%$ confidence interval limits were also calculated for the trial population. Statistical data processing was performed using IBM SPSS version 20. 


\section{RESULTS}

\subsection{Anthropometric and clinical data of patients entered in the study}

Total of 97 patients were entered in the study. The mean age of participants was $38.77(\mathrm{SD} \pm 9.69)$ years. The minimum age was 19 years; the maximum age was 81 years; the range of age was 62 years. Number of patients by gender, average age, BMI (before and $3-4$ years after surgery), neck circumference, modal Mallampati class and tonsil sizes are listed in Table 3.1. The average BMI of patients before surgery was 28.25 ( $\mathrm{SD} \pm 3.38$ ), while, when evaluating late results, it was 28.61 ( $\mathrm{SD} \pm 3.71$ ). In the assessment $\mathrm{T} 2$, the average BMI of all patients was all-in-all statistically significantly increased $(\mathrm{p}=0.04)$.

Table 3.1.

\section{Demographic, anthropometric, physical data of patients}

\begin{tabular}{|l|l|l|}
\hline Demographic and clinical data & Result $-\mathrm{TO} \pm \mathrm{SD}$ & Result $-\mathrm{T} 2 \pm \mathrm{SD}$ \\
\hline Men & 87 & $\times$ \\
\hline Women & 12 & $\times$ \\
\hline Ages of men (years) & $38.83 \pm 9.63$ & $\times$ \\
\hline Ages of women (years) & $38.33 \pm 10.52$ & $\times$ \\
\hline BMI $\left(\mathrm{kg} / \mathrm{m}^{2}\right)$ & $28.25 \pm 3.38$ & $28.61 \pm 3.71$ \\
\hline Neck circumference $(\mathrm{cm})$ & $41.56 \pm 1.69$ & $\times$ \\
\hline Mallampati (class) & Modal $=2$ & $\times$ \\
\hline Tonsil size (degree) & Modal $=0$ & $\times$ \\
\hline
\end{tabular}

Results TO - data obtained before ST. Results T2 - data obtained 3 to 4 years after ST. BMI - body mass index; Mallampati class - soft palate visualization degree.

Only snoring without any significant respiratory disorders was observed in 35 patients; 31 patient had OSA I (mild); 15 patients had OSA II (moderate); and 16 patients suffered from OSA III (severe). The mean BMI of all patients 
was 28.25 , but by groups: snorers -25.66 , OSA I -27.01 , OSA II -28.92 , OSA III - 30.54 (Figure 3.1).

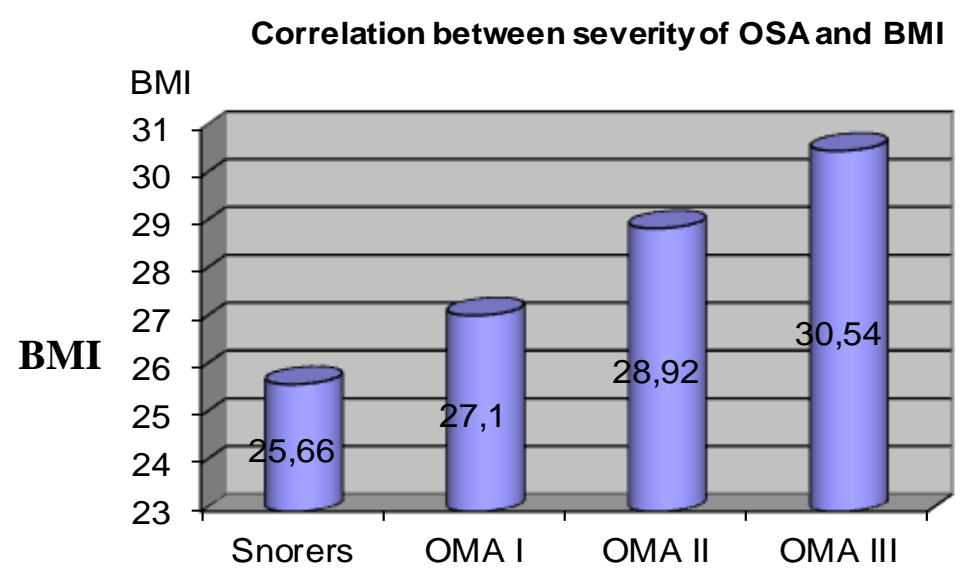

Figure 3.1. Correlation between severity of OSA and BMI

More severe sleep apnea was observed in patients with higher BMI. Using Pearson's correlation coefficient analysis it was concluded that there is positive, medium and statistically significant correlation $(r=0.45, p<0.001)$ between AHI-T0 and BMI-T0. An increase of BMI leads to an increase of AHI. Using linear regression analysis, it was concluded that there is the following equation between $\mathrm{AHI}$ before treatment and $\mathrm{BMI}$ : pre-treatment $\mathrm{AHI}=$ $52.83+2.54 \times \mathrm{BMI}$, the constant and the coefficient of the equation are statistically significant (corresponding $\mathrm{t}=-3.62, \mathrm{p}<0.001$ and $\mathrm{t}=4.88$, $\mathrm{p}<0.001$ ). The coefficient of determination of a linear regression model is 0.45 .

\subsection{Assessment of efficiency of surgical treatment}

The objective assessment. PSG after ST was repeatedly performed in 62 patients. The objective results of ST were compared (obj.-T0 and obj.-T2). 
The objective assessment showed that out of 62 patients 11 suffered from snoring and 51 patient had various degrees of OSA, and in this group of patients, good post-ST results $(\mathrm{AHI}<10)$ were in 17 (33.3\%) patients, satisfactory results $(\mathrm{AHI}<20$, but decreased by $50 \%)$ were $14(27.4 \%)$ patients, while unsatisfactory results were in 20 (39.2\%) patients. Overall, 31 (60.7\%) of OSA patients had satisfactory results, while among the snorers objectively better results had 6 out of 11 patients. Overall, among 62 re-examined patients (obj-T2), improvement was observed in 35 (56.4\%) patients. Average values of AHI by groups of diagnoses before (AHI-T0) and $3-4$ years after (AHI-T2), as well as the mean $\mathrm{SpO}_{2}$ is shown in the table (Table 3.2.).

Table 3.2.

Number of patients and average AHI-TO and AHI-T2 indices by groups of diagnoses in OSA patients and mean $\mathrm{SpO}_{2}$ before and after $\mathrm{ST}$ in patients with repeated PSG, PG data

\begin{tabular}{|l|l|l|}
\hline $\begin{array}{l}\text { Severity of respiratory disorders } \\
(\mathrm{n}=51)\end{array}$ & T0 & T2 \\
\hline AHI mean (episodes/h) & $21.51 \pm 18.4$ & $12.24 \pm 16.3$ \\
\hline Snoring AHI<5 (n=11) & $3.11 \pm 1.6$ & $8.4 \pm 6.3$ \\
Better $(\mathrm{n}=6)$ & $4.32 \pm 2.1$ & $3.16 \pm 1.5$ \\
Worse (n=5) & $3.15 \pm 1,6$ & $9.42 \pm 3.6$ \\
\hline mild OSA AHI 5-15 $(\mathrm{n}=24)$ & $10.92 \pm 2.91$ & $8.06 \pm 6.12$ \\
Better $(\mathrm{n}=15)$ & $11.48 \pm 3.24$ & $5.32 \pm 4.7$ \\
Worse $(\mathrm{n}=7)$ & $11.26 \pm 4.1$ & $14.73 \pm 16.8$ \\
\hline moderate OSA AHI 15-30 $(\mathrm{n}=12)$ & $24.3 \pm 14.09$ & $14.05 \pm 10.82$ \\
Better $(\mathrm{n}=7)$ & $25.54 \pm 4.2$ & $7.09 \pm 2.6$ \\
Worse $(\mathrm{n}=5)$ & $21.04 \pm 8.1$ & $23.80 \pm 6.1$ \\
\hline severe OSA AHI>30 $(\mathrm{n}=15)$ & $51.24 \pm 17.01$ & $21.16 \pm 11.87$ \\
Better $(\mathrm{n}=7)$ & $43.46 \pm 13.4$ & $13.67 \pm 5.8$ \\
Worse $(\mathrm{n}=8)$ & $48.93 \pm 20.8$ & $94.76 \pm 1.73$ \\
\hline mean $\mathrm{SpO} \%$ & $93.81 \pm 2.50$ & \\
\hline
\end{tabular}


AHI - number of apnea and hypopnoea episodes per hour of sleep, mean $\mathrm{SpO}_{2} \%$-mean oxygen saturation in blood.

The subjective assessment. Conducting patients' survey 4-6 months after surgery, we obtained data from 94 patients (subj.-T1). Conducting patients' survey after 3-4 years, we received responses from 67 patients. Conducting survey of patients and their bed partner, we found that, in early period, subj.-T1 of 94 surgically treated patients 75 (79\%) showed improvement, while in 19 (20\%) patients improvement was not reported. Assessment of late post-operative results subj.-T2 $(n=67)$ showed that 39 $(58.2 \%)$ patients experienced improvement, in 18 (26.8\%) patients improvement was not observed, but the condition of 10 (15\%) patients had worsened (Table 3.3.). Patients with assessment "worse", in further analysis were merged with those who had "no change" and further on they were called "no change", as in both cases results were unsatisfactory. Overall, positive results in subjective assessment (subj.-T2) were in $38(56.7 \%)$ patients out of 67 ; better, but without changes - in 29 (43.3\%) patients (Table 3.3.).

Table 3.3.

\section{Number of patients and subjective assessments of ST results in periods subj.-T1and subj.-T2}

\begin{tabular}{|l|c|l|l|}
\hline Survey data & T0 $(n=97)$ & T1 $(n=94)$ & T2 $(n=67)$ \\
\hline Better & $\times$ & 75 & 38 \\
\hline No change & $\times$ & 19 & 19 \\
\hline Worse & $\times$ & 0 & 10 \\
\hline
\end{tabular}

\subsection{Surgeries used for surgical treatment}

Overall, 157 surgeries were performed on 97 patients, 65 patients underwent more than one surgery, and altogether 14 types of surgeries were used. UPP and UPPP were the basic techniques which were supplemented with 
surgeries for improvement of nasal breathing and/or surgeries for expansion of airway at tongue base level. The most common combinations were UPP + RP in 20 surgeries; UPP + RFTBR - in 3 surgeries; UPPP + RP - in 9 surgeries. In cases of three surgeries, UPP or UPPP + RP + RFTBR were combined, in one case there was a combination of UPP $+\mathrm{RP}+\mathrm{GA}$.

\subsection{PSG results and impact of certain physical parameters on objective results of ST $(n=62)($ obj-T2)}

AHI. Impact of AHI was assessed only in 51 OSA patients with objective results (obj-T2). Assessment of AHI impact on ST results showed that among patients with AHI $<15$, "good" results were in 20 (39.2\%) patients, while the ones with unsatisfactory results were only 4 (7.8\%). In turn, in the group of AHI > 15, the number of unsatisfactory results increased reaching 9 (17\%) patients. Although no statistically significant link between pre-operative AHI and ST result was found, there is a tendency where the higher is AHI, the greater is a possibility of unsatisfactory results. Among patients with AHI> 30, good results are only in $6(12 \%)$ patients out of 51, while in the group of patients of AHI <30, "good" results are only in 23 (45.1\%) patients out of 51. Therefore, in cases where AHI> 30 unsatisfactory results occur more frequently.

Blood oxygen saturation $\left(\mathrm{SpO}_{2}\right)$. Pearson's correlation coefficient shoved positive, statistically significant correlation $(r=0.62$, $p<0.001)$ between AHI-T0 and mean $\mathrm{SpO}_{2}$-T0. The higher is AHI, the lower is mean $\mathrm{SpO}_{2}$. Based on the results of dependent sample t test, it was concluded that average blood oxygen saturation in assessments $\mathrm{T} 0$ and $\mathrm{T} 2$ of all patients differs by 0.80 units, and the difference is statistically significant $(\mathrm{p}<0.001)$. Using dependent sample $\mathrm{t}$ test, it was concluded that in patients with severe OSA AHI-T0 > 30, the mean $\mathrm{SpO}_{2}-\mathrm{T} 0(\mathrm{M}=91.35 ; \mathrm{SD} \pm 2.79)$ and after $\mathrm{ST}$ the mean $\mathrm{SpO}_{2}-\mathrm{T} 2(\mathrm{M}=92.71$; 
$\mathrm{SD} \pm 2.46)$ differs by $1.35 \%$, and this difference is statistically significant $(\mathrm{p}=0.04)$.

BMI. It was found that BMI was increased in 15 out of $22(68 \%)$ patients, whose results were without any changes. All-in-all, the mean BMI in this group of patients had increased by 1.2 units, but in 5 out of 10 patients with deteriorated condition the mean BMI had increased from 30.1 to $33.6 \mathrm{~kg} / \mathrm{m}^{2}$. Based on the results of independent sample t test, it was found that in those patients with deteriorated condition, the average BMI before and after ST differs statistically significantly $(\mathrm{p}=0.02)$. The average BMI had increased from $\mathrm{T} 0-29.50(\mathrm{SD} \pm 2.89)$ to $\mathrm{T} 2-30.65(\mathrm{SD} \pm 3.06)$ and this increase is statistically significant $(\mathrm{p}=0.01)$.

Neck circumference. Based on the results of independent sample t test, it was concluded that the average neck circumference with objective assessment "better" and "worse" differs statistically significantly ( $<$ <001). In the group of patients with improved condition, neck circumference in average was $41.16(\mathrm{SD} \pm 1.66)$, whereas in the group with deteriorated condition, it was $42.55(\mathrm{SD} \pm 1.63)$. Thus, results of surgery for patients with increased neck circumference more often were unsatisfactory.

Mallampati classes. Based on the results of Pearson's Chi-square test, it was concluded that there is a statistically significant relationship $(\mathrm{p}<0.001)$ between the Mallampati assessment T0 and the objective ST result T2. Thus, in patients with larger Mallampati class, more often the results were unsatisfactory.

Tonsil size. Based on the results of Pearson's Chi-square test, it was concluded that there is no correlation between tonsil size and the objective result $(\mathrm{p}=0.28)$. However, summarization of the results shows that the percentage of patients with tonsil size 2 and 3, good results were respectively three and five times more often. 
ESS. Based on the results of dependent samples $t$ test, it was concluded that the average ESS-T0 in all patients $=7.11( \pm 3.52)$ and after surgery ESS$\mathrm{T} 2=5.91(\mathrm{SD} \pm 2.58)$ differs statistically significantly $(\mathrm{p}<0.001)$. In turn, in patients with moderate or severe forms of OSA, this difference was higher and the average ESS-T0 $=9.32(\mathrm{SD} \pm 3.58)$ differs from the ESS-T2 $=7.07(\mathrm{SD} \pm$ 2.74) $(\mathrm{p}<0.001)$. This indicates on decrease of OSA-caused sleepiness, especially in patients with moderate and severe OSA, and on improvement of quality of life, which is an important result of treatment.

\subsection{PSG results and impact of certain physical parameters on subjective results of ST (subj.-T1 and subj.T2)}

The subjective assessment of patients with snoring most often was carried out by their bed partners. In mild forms, the problem was mostly social than medical and therefore the subjective assessment played the key role. There were also no medical indications to repeat PSG in this group of patients, and if a patient noted an improvement, the result was considered as good.

AHI. Based on the results of dependent sample t test, it was concluded that in OSA patients from subj.-T2 assessment group "better", after surgery the mean AHI decreased from $26.74(\mathrm{SD} \pm 17.91)$ to $8.44(\mathrm{SD} \pm 7.09)$ and differs statistically significantly $(\mathrm{p}<0.001)$. In case of subjective assessment "better", it is also reflected in objective results - in reduction of AHI according to a good and a satisfactory result.

BMI. Based on the results of independent sample $t$ test, it was found that in cases of subj.-T1 and subj.-T2 assessment "better" or "no change", the average BMI differs statistically significantly $(\mathrm{p}<0.001)$ in those whose results were without any changes or whose condition had worsened, - the average BMI is by 2.53 higher in $\mathrm{T} 2$ assessment than in those with improved conditions. In turn, in the group of 10 patients with worsened condition, the average BMI was increased from 29.45 to $31.55 \mathrm{~kg} / \mathrm{m}^{2}$. Thus, as in case of 
objective data, there is evident a strong correlation between negative ST results and weight gain.

Neck circumference. Based on the results of independent sample t test, it was concluded that the average neck circumference in case of subjective T2 assessment differs by $1.75 \mathrm{~cm}$ and this difference is statistically significant $(\mathrm{p}<0.001)$. Thus, similar to the objective assessment, better results were in patients with smaller neck circumferences.

Mallampati classes. Based on the results of Pearson's Chi-square test, it was concluded that there is a statistically significant correlation $(\mathrm{p}<0.001)$ between Mallampati and subjective T2 assessment. With an increase of Mallampati class (reduction in soft palate visualization degree), the result deteriorates. Like in the objective assessment, with an increase of Mallampati class the results, more likely, are negative.

Palatine tonsils. Using statistical analysis of chi-square ratio, it was found that there is statistically significant difference $(\mathrm{p}<0.001)$ between the size of tonsils and subj.-T2. Summarization of results showed that results with greater positive probability is in those patients with tonsil size 3 . In the objective data, statistically significant relationship of these parameters were not found, but in those patients with tonsils size 3, the percentage of good results was five times greater.

ESS. Based on the results of dependent sample t test, it was found that in cases of moderate and severe forms of OSA, the average ESS before surgery $9.32(\mathrm{SD} \pm 3.58)$ and after surgery $7.07(\mathrm{SD} \pm 2.74)$ differs statistically significantly $(\mathrm{p}<0.001)$. Thus, similar to the case with objective data, the reduction of sleepiness was observed in those patients. 


\subsection{Comparison of airway sagittal dimensions}

Upper airway sagittal dimensions of 63 patients were compared with the severity of their breathing disorders - AHI and BMI. We found statistically significant difference in uvular thickness (soft palate thickness- SPT) between patients with snoring and OSA III patients $(\mathrm{p}=0.001)$, as well as between snorers and OSA II patients $(\mathrm{p}=0.032)$. Variance analysis confirmed statistically significant difference in SPT in patients with different severity of OSAS ( $\mathrm{p}<0.001$ ), severity of respiratory disorder increases with an increase of uvular thickness. Statistically significant correlation was also found between the severity of OSA and airway sagittal size at tongue base level U-MPV $(\mathrm{p}<0.003)$.

Based on the results of independent samples t test, it was found that $\mathrm{U}$ MPV is the only sagittal airway size, which has statistically significant impacts on both the objective and the subjective results. Using ROC curve analysis, it was concluded that the U-MPV limiting value in subj-T2 patients was $9.00 \mathrm{~cm}$, the test sensitivity was $62 \%$ and specificity was $83 \%$. The area under the curve was 0.75 , so the weighted average [95\% TI: 0.63 to 0.88 ], $(\mathrm{p}<0.001)$ (Figure 3.2.)

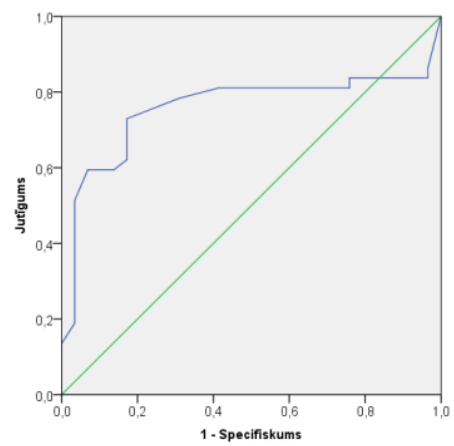

Figure 3.2. ROC curve characterizes impact of distance from tongue base to posterior pharyngeal wall (U-MPV) on a surgical result 


\subsection{Histological findings of upper airway soft tissue samples obtained during surgery}

Histological examination was carried out in 64 patients. Their histological changes were grouped by tissue types and severity levels of sleep breathing disorders; the following results were obtained: the most common histopathologic findings were: epithelium hyperplasia, tissue oedema, venous stasis, chronic inflammatory infiltration, mucus gland hyperplasia, scarring, muscular fiber atrophy and muscular fiber dystrophy. In some cases of severe OSA, there was hyperplasia of minor mucous glands with adenoma formation in one case, lymphangiectasia and muscle fiber hypertrophy. The severity of histological changes was divided accordingly: 0 - no change, 1 - minor changes, 2 - moderate changes, 3 - very explicit changes.

Statistically significant differences of the mean AHI index were observed in patients without epithelium hyperplasia $(\mathrm{p}=0.02)$ and with mild $(\mathrm{p}=0.011)$ epithelium hyperplasia, as well as in patients with very explicit epithelium hyperplasia. Regression analysis showed statistically significant interdependence between AHI index and epithelium hyperplasia - with an increase of severity of histological changes, the AHI index increase $(p<0.04)$. Calculating percentage ratio of tissue histological changes, statistically significant differences in distribution of histological changes in severity groups of OSA were observed in relation to tissue oedema and venous stasis $(\mathrm{p}=0.012)$, as well as to muscle fiber dystrophy $(\mathrm{p}=0.003)$. Assessment of pathomorphological changes in resected soft tissue samples obtained from OSA patients showed that the changes increase along with the severity of disease, however, no correlation between severity of changes and ST result was found. 


\subsection{Use of Bispectral index for determination of sleepiness}

Between the study and the control group, we found statistically significant differences between mean BIS $(p<0.001)$ and ESS $(p<0.0278)$ indices. Lower BIS indices and thus patients were sleepier in OSA group, where statistically significant differences were observed between the patients' group and the control group, from the 5th minute, except for 14th minute. In the control group, BIS scores were significantly higher, thus, the patients were more vigil. Statistically significant was also negative link between BIS indices and ESS. When BIS value increased by 1 unit, i.e., when a patient was more vigil, the ESS dropped by 0.34 ( $\mathrm{p}<0.001)$, which indicates the same. We found statistically significant differences between mean BIS indices in the control group and OSA patients (3.3.Fig.). In both groups, BIS index was associated with patients' level of sleepiness, according to their own assessment in the survey (ESS).

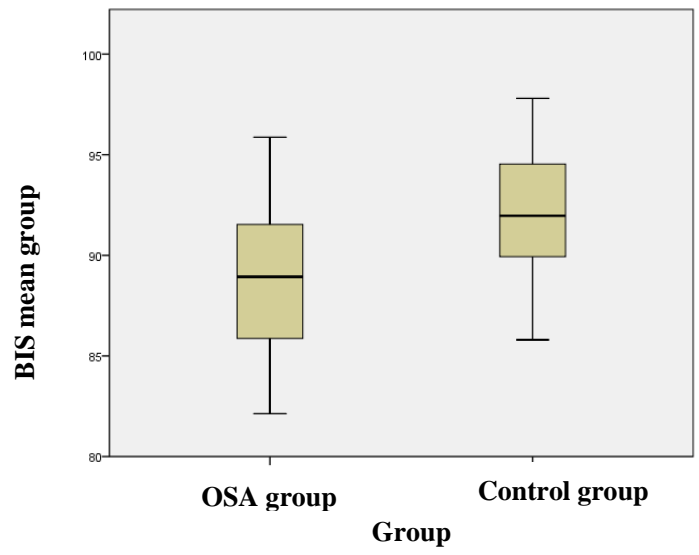

Figure 3.3. Mean BIS indices in both groups of the study 


\subsection{Complications}

Complications were divided by periods: early (postoperative) period and late period (summarizing T2 results). Causes of complications were also assessed: OSAS-related complications and ST-related complications. OSASrelated complications were the following: intubation in 3 (3.1\%) patients succeeded only after repeated attempts. Desaturation $<90 \% \mathrm{SpO}_{2}$ was observed in $8(8.5 \%)$ patients at early postoperative period. Perioperative hypertension was observed in $16(17 \%)$ patients with OSAS.

ST-related complications during postoperative period had $23(24.4 \%)$ patients, the dominant complaint of $20(21.2 \%)$ patients was severe pain in pharynx and painful swallowing, 11 (11.7) patients noted feeling of a foreign body in the throat $2-3$ weeks after surgery, 5 patients complained on a slight bleeding. In three cases, there was repeated bleeding during postoperative period, of which in 1 case, repeated surgery was necessary in order to stop bleeding. Summarizing late results of ST (T2), complications were observed in $12(12.7 \%)$ patients, but they did not cause any major inconveniences for those particular individuals: in 4 cases, patients complained of dry mouth, 3 patients had slight velopharyngeal insufficiency, 4 patients experienced a feeling of a foreign body in the throat. None of the patients noted any significant ST-related problems. 


\section{DISCUSSION}

\subsection{Description and comparison of surgical treatment results}

First publications targeted on description of OSA ST results, mainly focused on descriptions of UPP and UPPP. First articles on the subject were published in 1980s by Fujita et al, Zohar and Weingarten. For about 15 following years, UPP and UPPP were basic methods used in OSA surgical treatment. At that time, many articles were published showing rather optimistic results. In 1996, Pepin et al published critical analysis of snoring and OSA surgical treatment results. The authors found that UPP, UPPP and other techniques are often used to treat OSA, however, no methodological criteria were developed to support objective comparison of the above techniques [15]. In 1996, Sher et al [12] defined criteria for successful surgical treatment of OSA. On the basis of these criteria, several analyses of ST results were conducted. Sher's meta-analysis included more than 500 cases from 37 studies that met the selection criteria. It was found that, according to the set positive result criteria, only $39 \%$ of OSA patients had positive treatment results. ST treatment results found in further studies were considerably different. Coleman [16] noted $90 \%$ of cases with successful results in treatment of snoring, Walker [17] et al noted full cure of snoring in $60 \%$ of cases, partial cure in $29 \%$ of cases, and no improvement was observed in $10 \%$ of cases.

Caplis [18] in his meta-analysis found multi-level surgery (MLS) as the most effective UA soft tissue surgery for OSA. Coupling UPPP and RFTBR, the average efficiency was 30-60\% (4.1. Fig.). Verse obtained similar results after analysis of treatment results in 1360 patients after MLS. In average, AHI decreased from 43.4 to 19.3 and a successful result was found in $51 \%$ of cases [19]. 


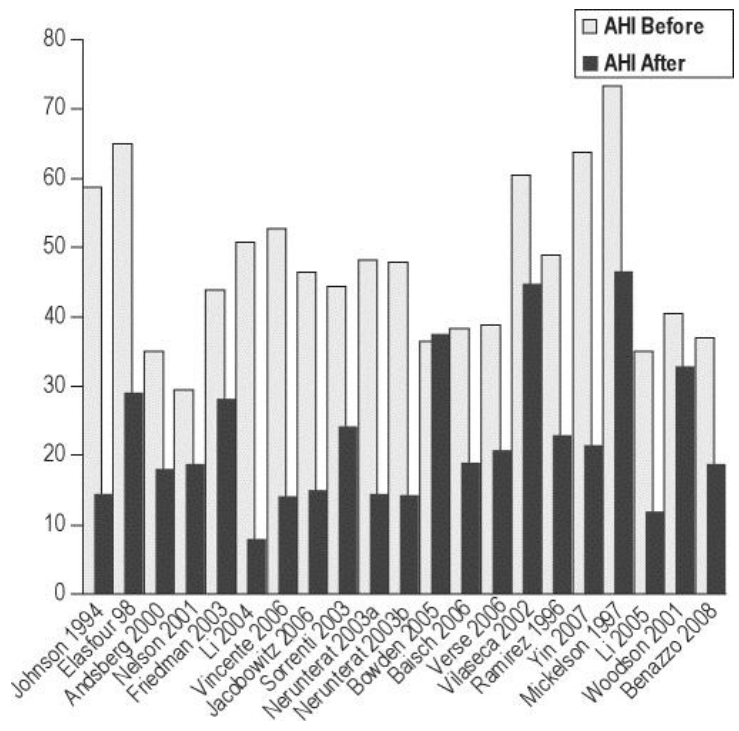

Figure 4.1. Correlation of mean indices after multiple level surgery Comparison of the AHI mean indices before and after surgeries in 21 study

\subsection{The analysis of our study results and comparison with results of other studies}

Our study was aimed at analysis of ST efficiency without emphasis on any particular type of surgery. In most cases, several surgeries were performed. From the beginning of the study in 2002 through 2005, UPP was the basic ST technique. Summarizing the first subjective results $3-6$ months after surgery, 29 out of 39 surgically treated patients $(71.8 \%)$ showed good results. As late post-surgical results after UA surgery, are considered results summarized more than 2 years after surgery. From 2005 to 2006, first late results -3 to 4 years after surgery - were summarized. At the time, such patients amounted to 48 . Positive results were found in 18 (37.5\%) patients only. After 2006, the tactic of ST changed. UPPP was mainly used as the key technique, by this 
understanding also TE in cases of enlarged tonsils. Agreeably to the existent classification of ST methods, MLS was used.

Summarizing data obtained for the whole period and comparing them with data of other studies, the objective PSG data showed that during 3 to 4 year post-surgical period, ST was successful in 35 out of 62 patients or in $56.4 \%$ of cases and in 39 or $58.2 \%$ of cases of patients' subjective assessment. In general, mean AHI in 62 patients had dropped from 21.5 to 12.2 events/hour. The analysis of positive results by groups of diagnoses showed the following: mean AHI in OSA I group had dropped from 11.48 to 5.32, in OSA II group from 24.54 to 7.09, in OSA-III group - from 43.81 to 13.67. Mean $\mathrm{SpO}_{2}$ values in the group of treated patients has generally risen from $93.81 \%$ to $94.76 \%$, while in the group of moderate to severe patients, the increase was more significant - from $90.34 \%$ to $93.2 \%$. Similar results were observed in other studies as well [20]. The drop of numbers of respiratory disturbances reduces activity of SNS and load on the cardiovascular system, accordingly reducing the incidences of complications. Reduction of sleepiness gives evidence of decrease of OSA cognitive aftereffects and improvement of a quality of life [21]. Patients' survey results showed that the total numbers of ESS has dropped from 7.11 points to 5.91 points, which is consistent with other studies. Numerically and clinically significant reduction is in group of moderate and severe patients - in average from 9.31 to 7.07. Comparing the results obtained in our study with the results of Keipla meta-analysis, we found that they are resembling as well as anthropometric and clinical data of patients were also quite similar.

\subsection{The analysis of factors affecting ST results}

Our study found statistically significant correlation between BMI and AHI ( $p<0.001)$. Cheng has analysed LAUPP results in 192 patients with overall 
positive result in $87 \%$ cases, but when BMI> 30, the possibility of good results has dropped significantly $(\mathrm{p}<0.01)$ [22]. Using ROC curve analysis, we found that BMI-T0 limiting value in subj-T2 assessment case was 29.70; test sensitivity was $54 \%$ and test specificity was $78 \%$. The area under the curve was 0.71, thus, the weighted average [95\% TI: 0.57 to 0.86], $(\mathrm{p}<0.001)$ (Figure 4.2.) In the group of patients with unsatisfactory results, BMI had increased by 1.15 units, and it is statistically significant $(\mathrm{p}=0.01)$.

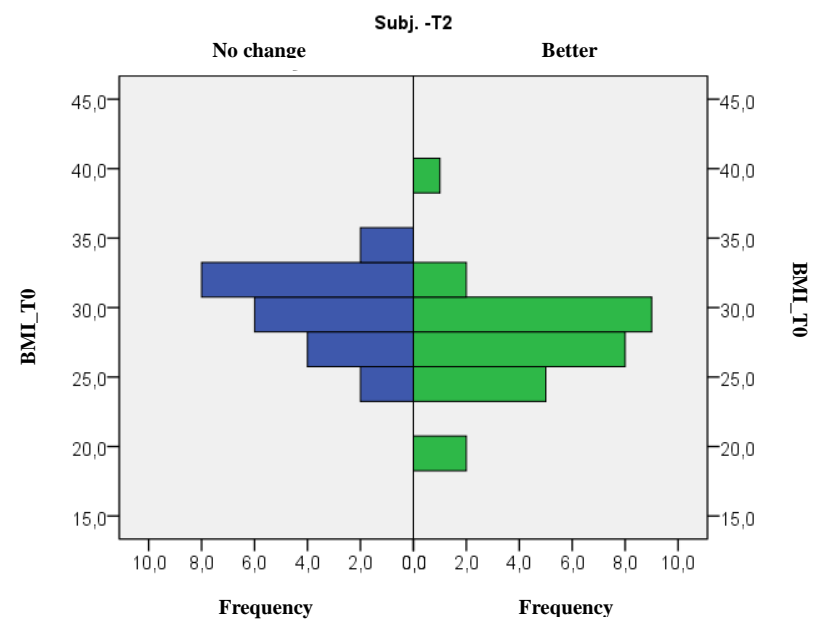

Figure 4.2. Correlation between BMI and ST result in obj-T2 assessment

Results in the group of snorers were better than in OSA group both by the subjective and the objective indices. Similar conclusions were reached by Laureto [23] and Vilaseca [24], who described significantly better results for snorers than for OSA patients. Many publications state that in cases of severe forms of OSA, ST results are worse. Also in guidelines for OSAS treatment, positive airway pressure (PAP) therapy is indicated as the first choice for severe forms of the syndrome; level of evidence I, II, grade of recommendations - standard [25]. 
Tonsilectomy can be very effective for achieving good ST results in cases of young patients with high AHI and palatine tonsil hypertrophy (size 3 4) as the main cause of UA obstruction. In this situation, a minor surgery can completely eliminate breathing disorders and, compared to PAP, it is radical and one-off manipulation. Friedman, Chen [26] and $\mathrm{Li}$ [27] have proven that tonsil size has a statistically significant positive impact on ST results. In our study, patients with tonsil sizes 2 and 3 had positive ST results in 18 (78\%) out of 23 cases.

Data of our study show that Mallampati class has a statistically significant relationship with ST result in both - the subjective and the objective assessments, and this link in both cases is statistically significant $(\mathrm{p}<0.001)$. An increase in Mallampati class decreases the possibility of positive ST result. Barcelo et al has analysed predicators of severe forms of OSA and has found that tonsil size, BMI, neck circumference, age and gender are associated with the severity of OSA, but Mallampati class is statistically the most significant predicator [28].

Neck circumference is also one of known prognostic factors of OSA, and it is often included in various OSA screening models [29]. Using the results of ROC curve analysis, it was found that limiting value of neck circumference in OSA patients of our study was $42.50 \mathrm{~cm}$, test sensitivity was $69 \%$ and test specificity was $80 \%$. The area under the curve was 0.84 , thus, assessed as good [95\% TI: 0.73 to 0.95 ]: $(\mathrm{p}<0.001)$ (Figure 4.3.) In our data, limiting value at which the results most likely will be unsatisfactory is $42.5 \mathrm{~cm}$. 


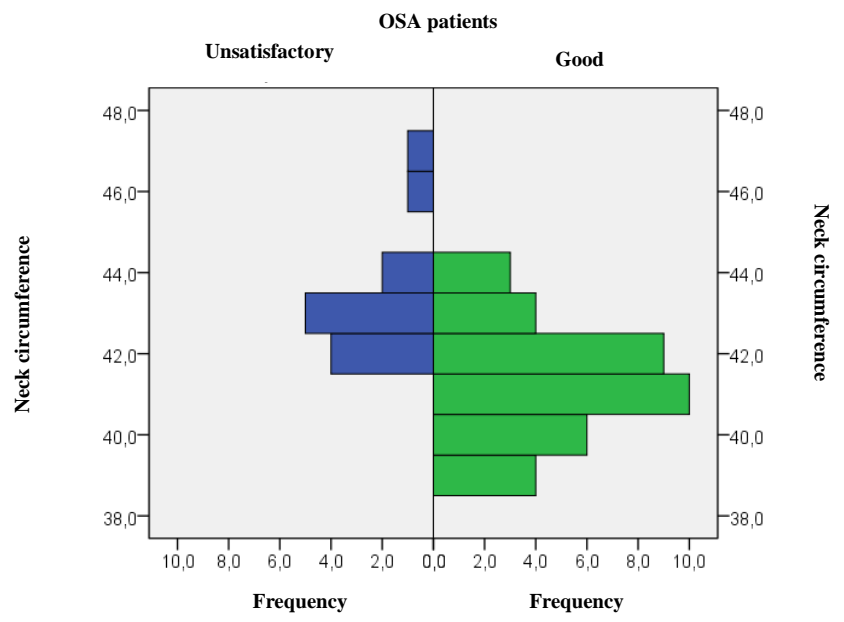

Figure 4.3. Graphic image of ROC curve showing correlation between neck circumference and ST results

Of cephalometric indices that could affect ST results in our study, we must indicate thickness of uvula (soft palate thickness- SPT) and distance from tongue base to posterior pharyngeal wall (U-MPV). With the raise of OSA severity, uvulas were thicker $(\mathrm{p}<0.003)$ and oropharynx cross-section at tongue base level (U-MPV) was lower $(\mathrm{p}<0.001)$. In many cases, oropharynx crosssection at tongue base level, is referred as posterior airway space (PAS) and is often considered as valuable predictor of ST results. Using the results of ROC curve analysis, it was found that SPT subj-T2 limiting value in patients was $11.2 \mathrm{~cm}$, test sensitivity was $57 \%$ and tests specificity was $61 \%$. The area under the curve was 0.61, thus, assessed as weak [95\% TI: 0.46 to 0.95]. Though, it must be noted that ROC curve of SPT is not statistically significant $(\mathrm{p}=0.15)$, hence this size was not included in the model for selection of patients. Using the results of ROC curve analysis, it was found that subj-T2 U-MPV limiting value in patients was $9.00 \mathrm{~cm}$, test sensitivity was $62 \%$ and test specificity was $83 \%$. The area under the curve was 0.75 , thus, assessed as moderate [95\% TI: 
0.63 to 0.88 ], $\quad(\mathrm{p}<0.001) \quad$ (Figure 4.4.) Thus, with a decrease of glossopharyngeal slit cross-section cut size $<9 \mathrm{~cm}$, the possibility of a successful result decreases.

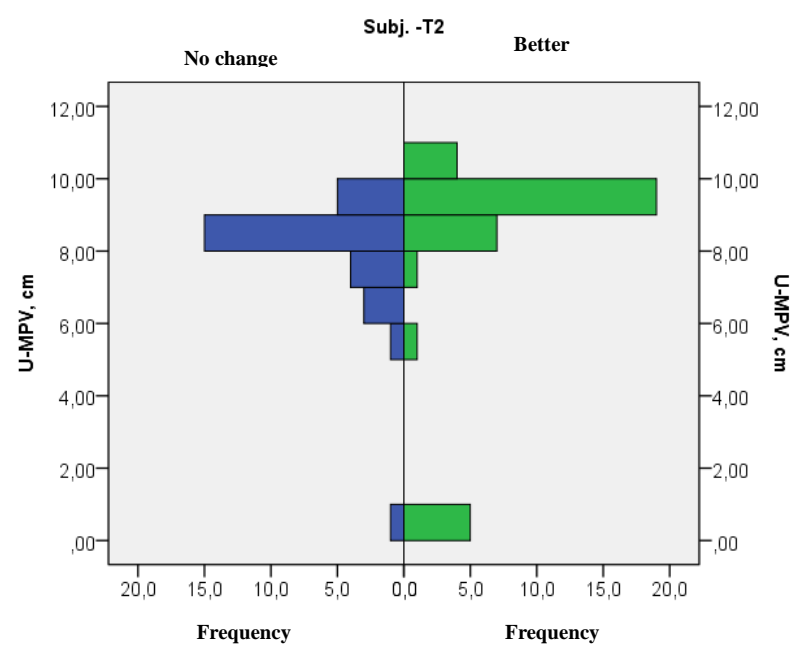

Figure 4.4. Graphic image of ROC curve showing correlation between U-MPV and ST results

Numerous publications starting from 1990-s indicate on pathomorphologic changes in UA soft tissues. Initially, this process was called snorer's disease [30]. In the process of snoring, traumatization of tissue occurs due to mechanical factors when the said tissues are lastingly exposed to vibrations. In the result of these pathological processes, respiratory function suffers, and airways are no longer able to fully participate in the process of breathing. Inflammatory changes originate oedema, tissue atrophy and connective tissue proliferation, which increases the volume of tissue and wherewith airway narrowing [31]. We found pathohistological changes in UA soft tissues while studying samples of resected UA soft tissue. The most 
common pathomorphological changes have been associated with inflammation, as well as with muscle fibre atrophy and dystrophy. In our study, we also found a statistically significant correlation between the level of pathomorphological changes and the severity of OSA, BMI and age. With an increase of AHI, BMI and age, changes become more explicit. It is likely that this finding is affecting ST result as AHI, BMI and age is ST-affecting measurements. Process of aging changes the flexibility of soft palates similarly to OSA.

Logistic regression analysis of ST results-affecting factors shows that statistically significant results is influenced by age, neck circumference, BMI, and U-MPV (Table 4.1.). Thickness of uvula more likely advances a positive ST result in the early assessment period, as greater tissue volume gets resected, but thicker uvulas are found in patients with larger BMI and thicker neck and more severe OSA, and in these cases, ST results are generally worse.

Table 4.1.

\section{Statistically significance of ST results prognostic factors}

\begin{tabular}{|l|l|l|c|}
\hline \multicolumn{1}{|c|}{ Title } & $\begin{array}{l}\text { No change, } \\
\mathrm{M} \pm \mathrm{SD}\end{array}$ & $\begin{array}{l}\text { Satisfactory } \\
\text { (good }+ \\
\text { satisfactory), } \\
\mathrm{M} \pm \mathrm{SD}\end{array}$ & $\mathrm{p}$ \\
\hline Age (years) & $2.91 \pm 11.28$ & $35.89 \pm 8.51$ & 0.01 \\
\hline $\begin{array}{l}\text { Neck circumference } \\
(\mathrm{cm})\end{array}$ & $42.50 \pm 44$ & $40.75 \pm 1.73$ & $<0.001$ \\
\hline BMI-T0 (kg/m $\left.{ }^{2}\right)$ & $29.36 \pm 2.68$ & $26.8 \pm 3.51$ & $<0.001$ \\
\hline M SpO ${ }_{2}$-T0 (\%) & $93.56 \pm 2.84$ & $94.48 \pm 2.17$ & 0.13 \\
\hline AHI-T0 (episodes/h) & $8.20 \pm 15.24$ & $19.17 \pm 18.15$ & 0.81 \\
\hline SPT (cm) & $11.25 \pm 1.12$ & $10.84 \pm 0.99$ & 0.16 \\
\hline U-MPV (cm) & $7.83 \pm 1.75$ & $9.48 \pm 3.31$ & 0.03 \\
\hline ESS-T0 (points) & $6.50 \pm 2.87$ & $7.38 \pm 3.57$ & 0.27 \\
\hline
\end{tabular}


BMI - Body Mass Index, mean $\mathrm{SpO}_{2}$, AHI -apnea-hypopnoea index, SPT - thickness of uvula, U-MPV - oropharynx narrowest place at tongue base level, ESS - Epwoth sleepiness scale, $\mathrm{M}$ - mean values, $\mathrm{SD}$ - standard derivation

Based on the results of Pearson's correlation coefficient analysis, we concluded mutual link between the variables (Table 4.2.). Factors which are most commonly associated with others, are BMI, ESS, and SPT; each of them is associated with 6 of 7 comparison values, $\mathrm{AHI}$ - with 5 of 7 values.

Table 4.2.

\section{Analysis of Pearson's correlation coefficient}

\begin{tabular}{|c|c|c|c|c|c|c|c|c|}
\hline Variables & है & 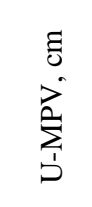 & $\underset{\infty}{\infty}$ & 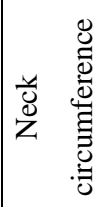 & $\stackrel{\circ}{\stackrel{P}{E}}$ & $\begin{array}{l}0 \\
\dot{1} \\
\dot{2} \\
\text { II }\end{array}$ & 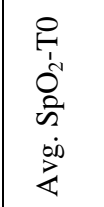 & 皇 \\
\hline SPT & & 0.085 & $0.478 *$ & $0.635^{*}$ & $0.680 *$ & $0.453^{*}$ & $0.590^{*}$ & $0.636^{*}$ \\
\hline U-MPV & & & 0.051 & $0.162 *$ & $0.207 *$ & 0.053 & 0.082 & $0.041 *$ \\
\hline Age & & & & $0.365^{*}$ & $0.260 *$ & 0.099 & $0.457 *$ & 0.127 \\
\hline $\begin{array}{l}\text { Neck } \\
\text { circumference. }\end{array}$ & & & & & $0.778^{*}$ & 0.148 & $0.503^{*}$ & $0.363^{*}$ \\
\hline BMI-T0 & & & & & & $0.318^{*}$ & $0.496^{*}$ & $0.457 *$ \\
\hline ESS-T0 & & & & & & & $0.376^{*}$ & $0.563 *$ \\
\hline Avg.Sp0 $0_{2}-\mathrm{T} 0$ & & & & & & & & $0.634 *$ \\
\hline AHI-T0 & & & & & & & & \\
\hline
\end{tabular}

* variables with statistically significant link $\mathrm{p}<0,05$

The obtained results coincide with results of most other studies. 
Obesity has been proved as dominant OSA predisposing factor. Type of obesity also plays a certain role here, namely, intra-abdominal (visceral) fat accumulation is less favourable than the dominant extra-abdominal fat allocation [32]. In cases of intra-abdominal obesity, increase in neck circumference is also usually observed, which clinically confirms the said fact; it is visible during examination of a patient. In other words - they are individuals with hyperstenic bodily structure, short and thick neck, fat cheeks and double chin [33].

When interpreting the role of these same factors in prognosis of ST results, the following similarities are evident: worse results are in elderly patients with elevated $\mathrm{BMI}>28.5 \mathrm{~kg} / \mathrm{m}^{2}$, thicker necks $>42.5 \mathrm{~cm}$, more severe forms of OSA and anatomically narrowed airway at tongue base area $<9 \mathrm{~cm}$, and percentage of results clearly indicate on affect of tonsil size on ST results. Link between of OSAS and obesity has been proven, while obesity, in turn, is determined by genetic factors, phenotype and habits [34]. Allocation of fat in the area of neck and formation of pharyngeal fat pads is associated with genetic factors and aging [35]. Specific genes that are responsible for the development of OSAS are being searched in the human gene map. Although genotypes, under influence of surrounding factors may manifest in a variety of phenotypes [36], some scientists believe that the development of OSAS is strongly genetically grounded [37]. We can conclude that in order to improve ST result, individual genotype and phenotype characteristics, family and personal medical histories and habits must be taken into account.

\subsection{Bispectral Index (BIS)}

In recent years, there are published data showing that intensive care patients are suffering from serious sleep diprivation, although a quality night's sleep should be a part of treatment [38]. BIS index is referred to be a useful 
tool in measurement of sleep parameters just in these circumstances. Determination of BIS is relatively simple and economical method which is capable to identify sleepiness and potentially can be used for objective determination of increased sleepiness. To date, no studies on this subject are found in databases, but objective and simple method for this purpose is still unfound. The only method used so far, is Multiple Sleep Latency Test (MSLT), which is conducted after a full-night PSG, it take all day and is expensive technique [39]. Our results suggest on a link between BIS and ESS. To confirm the above, standardized and randomized studies in larger groups of patients should be conducted.

\subsection{Complications}

Complications after OSAS surgical treatment can be divided into two groups. The first group would be comprised of complications associated with OSAS accompanying diseases. After analysis of 3130 cases, Kezirian et al found serious complications such as bleeding, respiratory disorders, all-in-all in $1.5 \%$ patients, and lethality in $0,2 \%$ cases [40]. Most often, life-threatening complications are not related to the surgery itself, but to overall conditions of patients. From these types of complications, in 3 cases of our study we encountered problematic intubation, in 8 patients or $8.5 \%$ of cases desaturation $<90 \%$ was observed during the post-operative period. In patients with severe forms of sleep apnea, perioperative hypertension was often observed. No serious, life-threatening complications were present.

The second group of complications was associated with UA surgery itself, but mostly these complications did not cause any significant morbidity. Dominant complaints at the early postoperative period were the following: pain, difficulty swallowing, foreign body sensation in the pharynx. All operated patients had these complaints, but 23 of them (24.4\%) described them as strong. 
The most serious, life-threatening complication in our study was bleeding - in 1 case; re-operation was required to stop bleeding.

Late complications were observed in 12 or $12.7 \%$ of patients, they did not inflict any major inconveniences on the particular individuals: in 4 cases patients complained of dry mouth, 3 patients had a minor velopharingeal insufficiency, 4 patients noted a foreign body sensation in the throat, one patient experienced phlegm accumulation in the throat area. In general, the number of complications can be described as mild and without serious medical consequences. 


\section{CONCLUSIONS}

1. Using a method of lateral cephalometry, it was found that sagittal sizes of glossopharyngeal space and thickness of uvula are those morphological parameters that correlate with the severity of OSA, and glossopharyngeal space is a predicting factor of surgical treatment success.

2. Assessing pathomorphological changes in resected soft tissue samples obtained from obstructive sleep apnea patients, we found that changes tend to increase with the severity of the disease.

3. The analysis of surgical treatment outcome showed that, in subjective assessment of the results, $58 \%$ of patients evaluated results as good, but in objective assessment, good result were in $56 \%$ of patients. In general, the mean apnea-hypopnoea index and sleepiness of patients in the group of surgically treated patients has decreased, the average oxygen saturation in blood has increased and the rate of complications was low.

4. Surgical treatment results are influenced by patients' anthropometric (BMI, neck circumference, Mallampati class, tonsil size), clinical data (AHI) and the craniofacial morphology (width of glossopharyngeal space).

5. BIS index in OSA patients is lower compared to the control group of healthy individuals.

6. Using statistically significant links between individual parameters of individual patients and the results of surgical treatments, we have developed criteria for individual treatment plans. 


\section{PRACTICAL RECOMMENDATIONS}

1. In moderate and severe forms of OSA, Positive Airway Pressure treatment is the option of first choice.

2 Proper patients selection for ST plays the key role in achievement of positive and long-term results, and it should be based on :

- $\quad$ Sleep study data (PSG, PG),

- Patient's anthropometric, physical and anamnesis data,

- UA examination data: visualization, radiological and endoscopic data,

- Selection of appropriate ST tactic; the most effective ones are MLS techniques and MMA,

- To consider genetic and phenotypic aspects which may affect longterm results

3. The following criteria predicting good ST results should be included in patients' selection model:

- $\quad$ BMI $<29 \mathrm{~kg} / \mathrm{m}^{2}$

- $\quad$ Neck circumference $<42,5 \mathrm{~cm}$

- Glossopharingeal space $>9 \mathrm{~mm}$

- $\quad$ Mallampati class $\leq$ II

- $\quad$ Tonsil size $\geq 2$

4. To take into account the following factors influencing ST results:

- With increase in age, results deteriorate.

- With elevation of AHI, results deteriorate; can be exceptions.

- The longer is the history of disease, the results are worse.

- Patient's lifestyle, habits, family anamnesis may affect long-term results.

- Intra-abdominal obesity type is an additional risk factor. 
5. In cases where coexist UA size-reducing skeletal anomalies and severe OSA, phase II surgery - MMA should be considered.

6. Overweight and its increase after surgery may play a crucial role in long-term results, therefore, the involvement of a nutritionist is required. 


\section{AUTHOR'S PUBLICATIONS ON THE RESEARCH SUBJECT}

\section{Publications.}

1. J.Svaža, A.Skaǵers, D.Čakārne, I. Jankovska. Augšējo elpošanas ceḷu sagitālās dimensijas un polisomnogrāfiskie rādītāji pacientiem ar krākšanu un obstruktīvo miega apnoju. / RSU Zinātniskie raksti, 2009:166-73.

2. J.Svaža, L.Gūtmane. Pozitīva spiediena terapija efektivitāte un ietekme uz dzīves kvalitāti pacientiem ar vidēji smagu un smagu obstruktīvu miega apnoju. // RSU Zinātniskie raksti, 2011:7-14.

3. I.Fietze, T.Penzel, A.Alondersis, F.Barbe, Mr.Bonsignore, J.Svaza, et all. Management of obstructive sleep apnea in Europe. // Sleep Medicine, 2011;(12):190-97. (Pubmed PMID:21167776).

4. J.Svaza, A.Skagers, D.Cakarne, I.Jankovska. Upper airway sagittal dimensions in obstructive sleep apnea (OSA) patients and severity of the disease. // Stomatologija, Baltic Dental and Maxillofacial Journal, 2011;(13):124-28. (Pubmed PMID:22362339).

5. J.Svaza, I.Indriksone, M.Vitola, A.Aleksejevs. The Bispectral Index (BIS) as an instrumental method for the measurement of the Excessive Daytime Sleepiness (EDS). Pilot study // X World Congress on Sleep the Proceedings, Edizioni Minerva Medica, 2012:37-39. (ISBN: 978-887711-616-1).

6. J.Svaza, J.Grava, J.Smolko.Screening tools for identifying a high probability of obstructive sleep apnea. // Acta Medica Lituanica, 2012; (19),3:123-26. (ISSN: 1392-0138). 


\section{Reports and theses international congresses and conferences}

1. N.Limba, L.Aberberga-Augskalne, J.Svaza. Sleep quality, snoring and tonus of the autonomic nervous sistem: Pilot study // $23^{\text {rd }}$ ICPAFR International sport science symposium, Tartu, Estonia, 2002:35-36.

2. J.Svaža, A.Skaǵers. Obstructive sleep apnea siyndrome - results in diagnostic and treatment // International Conference, Klaipēda, 2004: 17.

3. A.Skagers, J.Svaza, D.Cakarne, L.Feldmane. Palatal and nasal surgery to diminish snoring and sleep apnea // 17th International conference on Oral \&Maxillofacial Surgery, Vienna, 2005:281.

4. J.Svaza, A.Skagers. Obstructive sleep apnea-hypoapnea syndrome results in diagnostics and treatment // 8th Joint symposium Rostock Riga, Stomatologija, Baltic Dental and Maxillofacial Journal, 2006; (1):35.

5. J.Svaza, A.Skagers. Obstructive sleep apnesa-hypopnes syndrome CPAP, surgical and orthodontic treatment // Thesis. $2^{\text {nd }}$ International Baltic Congress of Anaesthesiology and Intensive Care., $8^{\text {th }}$ Congress of Estonian Anaesthesiologists, Tallinn, Estonia, 2006:108.

6. A.Skagers, J.Svaza, L.Feldmane, D.Cakarne. Palato - nasal surgery and snoring and obstructive sleep apnea. // Baltic Dental scientific Conference, Riga, Stomatologija, 2007; (1)4:24 - 25.

7. J.Svaža, L.Feldmane, I.Jankovska, A.Skaǵers. Pathomorphological changes of soft palate in snoring and obstructive sleep apnea (OSA) // 7th Congress of Baltic Association for Maxillofacial and Plastic Surgery, Riga Latvia, 2010:70.

8. Ю.В.Сважа, А.Скагерс, Д.Чакарне, И.Янковска.

Полисомнографические показатели храпа а также характеристика измерений в сагиттальной плоскости верхних дыхательных путей у 
пациентов страдающих обструктивным апноэ сна. // The $17^{\text {th }}$ international conference for maxillofacial surgeons and stomatologists, St.Petersburg, Russia, 2012:158-59.

9. J.Svaza, I.Indriksone, M.Vitola, A. Aleksejevs. The Bispectral Index (BIS) as an instrumental method for the measurement of the Excessive Daytime Sleepiness (EDS). Pilot study // X World Congress on Sleep Apnea. Abstract book 2012:58.

\section{Reports and theses congresses and conferences in Latvia}

1. J.Svaža, N.Limba, A.Skaǵers, D.Čakārne. Obstruktīvas miega apnojas sindroma diagnostika RSU Stomatologiijas institūta miega laboratorijā, ārstēšanas pirmie rezultāti // 2. Latvijas Anesteziologiijas, Reanimatoloǵijas, Intensīvās terapijas, Neatliekamās medicīniskās palīdzības un Katastrofu medicīnas kongress, Rīga, 2002:124.

2. J.Svaža, A.Skag̊ers, G.Jākobsone. Diagnostikas metožu salīdzinājums optimālas obstruktīvas miega apnojas ārstēšanas taktikas izvēlē // Tēzes. 5. Latvijas Ārstu kongress, 2005:43.

3. J.Svaža, A.Skaǵers, D.Čakārne, I.Jankovska. Augšējo elpošanas ceḷu sagitālās demensijas un polisomnorāfiskie rādītāji pacientiem, kuru cieš no krākšanas un obstruktīvās miega apnojas // RSU Zinātniskā konference, 2009:54.

4. J. Svaža. Obstruktīvās miega apnojas sindroma patoǵenēze, ietekme uz sirds asinsvadu sistēmu un vielmaiņu, tās klīniskās izpausmes. OMAS īpatn̄ibas bērniem un veciem cilvēkiem. Ārstēšanas iespējas// 6. Latvijas ārstu kongress, referāts. 2009. 
5. J.Svaža, L.Feldmane, A.Skaǵers. Mīksto auksleju patomorfolog̣iskās izmaiņas pacientiem ar krākšanu un obstruktīvo miega apnoju // Tēzes. RSU Zinātniskā konference, 2010:295.

6. J.Svaža, L.Gūtmane. Pozitīva spiediena terapija obstruktīvās miega apnojas ārstēšanā: pacientu līdzestība, dzīves kvalitātes vērtējums, biežākās blaknes // Tēzes. RSU Zinātniskā konference, 2011:33.

7. J.Svaža, D.Čakārne, I. Jankovska, L.Feldmane, A.Skaǵers. Augšējo elopšanas ceḷu cefalometriskie rādītāji un mīksto aukslēju patomorfologiskās izmaiņas pacientiem ar krākšanu un obstruktīvo miega apnoju //Apvienotais Pasaules Latviešu Zinātnieku 3.kongress un Letonikas 4.Kongress, medicīnas zinātne un Latvijas sabiedrības veselība XXI gadsimtā, Medicīnas sekcijas tēzes, Rīga, 2011:95-96.

8. J.Svaža, I.Indriksone. Liekā svara saistība ar obstruktīvās miega apnojas smaguma pakāpi un vidējo skābekḷa koncentrāciju asinīs // Tēzes. RSU Zinātniskā konference 2012:311.

9. J.Svaža, I.Indriksone. Bispektrālais indekss, miegain̄̄bas noteikšanai Obstruktīvās miega apnojas pacientiem // Tēzes. RSU Zinātniskā konference, 2013:85.

10. I.Indriksone, G.Jākobsone, J.Svaža. Kraniofaciālās morfoloǵijas un adenoīdu ietekme uz nazofaringeālo orofaringeālo elpceḷu izmēriem // Tēzes. RSU Zinātniskā konference, 2013:289. 


\section{LIST OF LITERATURE}

1. Punjabi N. M. The Epidemiology of Adult Obstructive Sleep Apnea // Proceedings of the American Thoracic Society, 2008; 5:136.- 43.

2. Netzer N.C., Hoegel J.J., Loube D., et al. Prevalence of symptoms and risk of sleep apnea in primary care // Chest, 2003; 124:1406-14.

3. Rodenstein D.O., Dooms G., Thomas Y., Liistro G., Stanescu D.C., Culee C., Aubert-Tulken G. Pharyngeal shape and dimensions in healthy subjects, snorers, and patients with obstructive sleep apnea // Thorax, 1990; 45:722-727.

4. Young T., Peppard P.E., Taheri S. Excess weight and sleep disordered breathing // J Appl Physiol, 2005; 99:1592-7.

5 . Parati G, Lombardi C, Hedner J, Bonsignore M.R, Grote L, Tkacova R, ar al. EU COST Action B26 members. Recommendations for the management of patients with obstructive sleep apnea and hypertension // Eur Respir J. 2013 Mar;41(3):523-38.

6. Foster G.D., Sanders M.H., Millman R., Zammit G., et al. Obstructive sleep apnea among obese patients with type 2 diabetes // Diabetes Care 2009; 32:1017-9.

7. Jennum P., Santamaria J. Members of the Task Force. Report of an EFNS task force on management of sleep disorders in neurologic disease (degenerative neurologic disorders and stroke) // Eur J Neurol, 2007; 14(11):1189-200.

8. Antonopoulos CN, Sergentanis TN, Daskalopoulou SS, Petridou ET. Nasal continuous positive airway pressure (nCPAP) treatment for obstructive sleep apnea, road traffic accidents and driving simulator performance: a meta-analysis // Sleep Med Rev, 2011; 15(5):301-10.

9. Friedman M. Sleep apnea and snoring: surgical and non-surgical therapy// ISBN 978-1-4160-3112-3, Elsevier Inc, 2009; 104-7. 
10. Friedman M., Ibrahim H., Joseph N.: Combined uvulopalatopharyngoplasty and radiofrequency tongue base reduction for treatment of obstructive sleep apnea/hypopnea syndrome // Otolaryngol Head Neck Surg 2003; 129(6):611-21.

11. Sher A.E., Schechtman K.B., Piccirillo J.F. The efficacy of surgical modifications of the upper airway in adults with obstructive sleep apnea syndrome // Sleep 1996; 19:156-77.

12. Kezirian E.J., White D.P., Malhotra A., et al., Interrater reliability of drug-induced sleep endoscopy // Arch Otolaryngol Head Neck Surg, 2010; 136:393-7.

13. Powell N.B., Riley R.W. A surgical protocol for sleep disordered breathing // Oral Maxillofac SurgClin North Ann, 1995; 7:345-56.

14. Aurora R.N., Casey K.R., Kristo D., Auerbach S., Bista S.R., Chowdhuri S., et al. American Academy of Sleep Medicine. Practice parameters for the surgical modifications of the upper airway for obstructive sleep apnea in adults // Sleep, 2010; 33(10):1408-13.

15. Pépin J.L., Veale D., Mayer P., Bettega G., Wuyam B., Lévy P. Critical analysis of the results of surgery in the treatment of snoring, upper airway resistance syndrome (UARS), and obstructive sleep apnea (OSA) // , 1996; 19(9):90-100.

16. Coleman J.A. Laser-assisted uvulopalatoplasty: long-term results with a treatment for snoring // Ear Nose Throat J, 1998; 77(1):22-4, 26-9, 32-4.

17. Walker R., Gopalsami C., Totten M., Grigg-Damberger M. Laserassisted uvulopalatoplasty for snoring and obstructive sleep apnea: Results in 170 patients // Laryngoscope, 1995; 105(9):938-43.

18. Caples S.M., at al. Surgical modifications of the upper airway for obstructive sleep apnea in adults: a systematic review and meta-analysis // Sleep, 2010; 33(10):1396-407. 
19. Verse T. Update on surgery for obstructive sleep apnea syndrome // HNO, 2008; 56:1098-104.

20. Dahlöf P., Norlin-Bagge E., Hedner J., Ejnell H., Hetta J., Hällström T. Improvement in neuropsychological performance following surgical treatment for obstructive sleep apnea syndrome // Acta Otolaryngol, 2002; 122(1):86-91.

21. Li H.Y., Huang Y.S., Chen N.H., Fang T.J., Liu C.Y., Wang P.C. Mood improvement after surgery for obstructive sleep apnea // Laryngoscope, 2004; 114(6):1098-102.

22. Cheng D.S., Weng J.C., Yang P.W., Cheng L.H. Carbon dioxide laser surgery for snoring: results in 192 patients // Otolaryngol Head Neck Surg, 1998; 118(4):486-9.

23. Lauretano A.M. Uvulopalatoplasty using laser-assisted techniques // Otolaryng Head Neck Surg, 2000; 11(1):7-11.

24. Vilaseca I., Morello A., Montserrat J.M., et al. Usefulness of uvulopalatopharyngoplasty with genioglossus and hyoid advancement in the treatment of obstructive sleep apnea // Arch Otolaryngol Head Neck Surg, 2002; 128(4):435-40.

25. Adult Obstructive Sleep Apnea Task Force of the American Academy of Sleep Medicine. Clinical Guideline for the Evaluation, Management and Long-term Care of Obstructive Sleep Apnea in Adults // J Clin Sleep Med, 2009; 5(3): 263-76.

26. Chen H., Ye H., Zhen Y., Zhang Z., Cai Q., Chen Q. The effect of the size of tonsil on uvulopalatopharyngoplasty // Lin Chuang Er Bi Yan Hou Ke Za Zhi. 2006; 20(8):355-7.

27. Li H.Y., Wang P.C., Lee L.A., Chen N.H. Fang T.J. Prediction of uvulopalatopharyngoplasty outcome: anatomy-based staging system versus severity-based staging system // Sleep, 2006; 29(12):1537-41. 
28. Barceló X., Mirapeix R.M., Bugés J., Cobos A., Domingo C. Oropharyngeal Examination to Predict Sleep Apnea Severity // Arch Otolaryngol Head Neck Surg, 2011; 137(10):990-6.

29. Chung F., Yegneswaran B, Liao P., et al. STOP Questionnaire. A Tool to Screen Patients for Obstructive Sleep Apnea // Anesthesiology, 2008; 108:812-21.

30. Friberg D. Heavy snorer's disease: a progressive local neuropathy // Acta Otolaryngol, 1999; 119(8):925-33.

31. Puig F., Rico F., Almendros I., Montserrat J.M., Navajas D., Farre R. Vibration enhances interleukin-8 release in a cell model of snoringinduced airway inflammation // Sleep, 2005; 28:1312-6.

32. Ogretmenoglu O., Suslu A.E., Yucel O.T., Onerci T.M., Sahin A. Body fat composition: a predictive factor for obstructive sleep apnea // Laryngoscope, 2005; 115(8):1493-8.

33. Fischer M.K., Martinez D., Cassol C.M., Rahmeier L., Vieira L.R. Immediate and overnight recumbence-dependent changes of neck circumference: relationship with OSA severity in obese and nonobese subjects // Sleep Med, 2012; 13(6):650-5.

34. Strohl K.P., Redline S. Recognition of obstructive sleep apnea // Am J Respir Crit Care Med, 1996; 154: 279-89.

35. Malhotra A., Huang Y., Fogel R., et al. Aging influences on pharyngeal anatomy and physiology: the predisposition to pharyngeal collapse // Am J Med, 2006; 119: 72

36. Riha R.L., Gislasson T., Diefenbach K. The phenotype and genotype of adult obstructive sleep apnea/hypopnoea syndrome // Eur Respir J, 2009; 33: 646-55. 
37. Casale M., Pappacena M., Rinaldi V., Bressi F., Baptista P., Salvinelli F. Obstructive Sleep Apnea Syndrome: From Phenotype to Genetic Basis // Curr Genomics, 2009; 10(2):119-26.

38. Thakur S., Kaur T., Kaur S., Bhagat H., Narayanan S., Bhardwaj N., et al. Awareness of bispectral index monitoring system among the critical care nursing personnel in a tertiary care hospital of India // Indian J Anaesth 2011; 55(6):563-6.

39. Carskadon M.A. Evalution of excessive day time sleepiness // Neurophysiol Clin, 1993; 23:91-100.

40. Kezirian E.J., Weaver E.M., Yueh B., Deyo R.A., Khuri S.F., Daley J., Henderson W. Incidence of serious complications after uvulopalatopharyngoplasty // Laryngoscope, 2004; 114(3):450-3. 